\title{
Erratum to: Effects of forest fires on forest ecosystems in eastern coastal areas of Korea and an overview of restoration projects
}

\author{
Young Sang Ahn $\cdot$ Soung-Ryoul Ryu $\cdot$ Joohoon Lim $\cdot$ Choong Hwa Lee $\cdot$ \\ Joon Hwan Shin · Won Il Choi · Byungdoo Lee · Jin-Hyun Jeong • \\ Ki Wan An · Jung Il Seo
}

Published online: 14 December 2013

(c) International Consortium of Landscape and Ecological Engineering and Springer Japan 2013

\section{Erratum to: Landscape Ecol Eng}

\section{DOI 10.1007/s11355-013-0212-0}

In the original publication, the current address of the co-author was not included. The correct affiliation should appear as in this article.

The online version of the original article can be found under doi:10.1007/s11355-013-0212-0.

Y. S. Ahn $(\bowtie) \cdot$ K. W. An

Division of Forest Resources, Chonnam National University, Gwangju 500-757, Korea

e-mail: ysahn@jnu.ac.kr

S.-R. Ryu

Department of Renewable Resources, University of Alberta,

Edmonton, Alberta T6G 2H1, Canada

J. Lim - C. H. Lee - J. H. Shin · W. I. Choi - B. Lee ·

J.-H. Jeong

Department of Forest Conservation, Korea Forest Research

Institute, Seoul 130-712, Korea

J. I. Seo

College of Earth, Ocean, and Atmospheric Sciences,

Oregon State University, Oregon 97331-5503, USA

Present Address:

J. I. Seo

Department of Forest Resources, College of Industrial Sciences, Kongju National University, 54 Deahakro, Yesaneup, Yesangun, Chungcheongnamdo 340-702, Republic of Korea 